\title{
ORIGINAL
}

\section{Capnometry levels as an indicator of renal graft evolution in uncontrolled non-heart beating donors}

\author{
A. Mateos Rodríguez ${ }^{\mathrm{a}, \mathrm{b}, \mathrm{e}, *}$, D. Varillas Delgado ${ }^{\mathrm{b}, \mathrm{e}}, \mathrm{A}$. Villar Arias $^{\mathrm{c}, \mathrm{e}}$, \\ C. Rubio Chacón ${ }^{c}$, A. Andrés Belmonte ${ }^{d}$
}

a Oficina Regional de Coordinación de Trasplantes, Consejería de Sanidad, Comunidad de Madrid, Spain

b Facultad de Ciencias de la Salud, Universidad Francisco de Vitoria, Pozuelo de Alarcón, Madrid, Spain

c Servicio de Urgencias Médicas de Madrid SUMMA112, Comunidad de Madrid, Spain

d Coordinación de Trasplantes, Hospital Universitario 12 de Octubre, Madrid, Spain

e Grupo de Investigación en Donación y Trasplantes, Universidad Francisco de Vitoria, Pozuelo de Alarcón, Madrid, Spain

Received 26 July 2018; accepted 30 October 2018

Available online 2 February 2020

\section{KEYWORDS \\ Capnometry; Kidney transplantation; Asystole; Resuscitation; Emergency medical services}

\begin{abstract}
Objective: The capnometry values during resuscitation are an evolutive predictor of kidneys obtained from uncontrolled non-heart beating donors.

Design: The study comprised a retrospective onset cohort of 37 non-heart beating donors and a validation cohort of 55 transplanted kidneys in the period 2013-2017.

Scope: The population served by the emergency service and referred to Hospital Universitario Doce de Octubre (Madrid, Spain) as potential uncontrolled non-heart beating donors.

Patients: A total of 55 renal transplant patients subjected to hemodialysis and with grafts from uncontrolled non-heart beating donors.

Interventions: Capnometry and capnography measurements in potential uncontrolled non-heart beating donors.

Variables: Capnometry values recorded initially and at transfer in hospital for comparison with the viability of the extracted kidneys; renal failure and delayed renal function.

Results: A total of 55 out of 74 extracted kidneys were transplanted (74.3\%). The rest were ruled out due to poor perfusion or signs of ischemia. An association was observed $(p=0.016)$ between the capnometry values during resuscitation in the grafted kidneys ( $\mu=22.8 \mathrm{mmHg}$ ) and in the kidneys discarded for transplantation $(\mu=17.35 \mathrm{mmHg})$.

Conclusions: Capnometry during resuscitation serves as a marker to be taken into account in relation to the viability of the transplanted organs in uncontrolled non-heart beating donors.

(c) 2018 Elsevier España, S.L.U. and SEMICYUC. All rights reserved.
\end{abstract}

\footnotetext{
is Please cite this article as: Mateos Rodríguez A, Varillas Delgado D, Villar Arias A, Rubio Chacón C, Andrés Belmonte A. Niveles de capnometría como indicador de evolución de injerto renal de donantes en asistolia no controlada. Med Intensiva.. 2020;44:233-238.

* Corresponding author.

E-mail address: alonso.mateos@salud.madrid.org (A.M. Rodríguez).
} 


\section{PALABRAS CLAVE}

Capnometría; Trasplante renal; Asistolia; Resucitación; Servicios de emergencias médicas
Niveles de capnometría como indicador de evolución de injerto renal de donantes en asistolia no controlada

\section{Resumen}

Objetivo: Los valores de capnometría durante la resucitación son un factor predictor de la evolución de los riñones obtenidos a partir de donantes en asistolia no controlada.

Diseño: Cohorte de comienzo retrospectivo de 37 donantes en asistolia, y cohorte de validación de 55 trasplantados de riñón, entre 2013-2017.

Ámbito: población atendida por el servicio de emergencias y derivada al Hospital Universitario 12 de Octubre, Madrid, como potenciales donantes en asistolia no controlada.

Pacientes: 55 trasplantados renales con hemodiálisis, procedentes de donantes en asistolia no controlada.

Intervenciones: determinaciones de capnometría y capnografía en pacientes candidatos a donación en asistolia no controlada.

Variables: Valores de capnometría inicial y en el momento de la transferencia en el hospital para su comparación con la viabilidad de los riñones extraídos; fallo renal y retraso en función renal.

Resultados: 37 potenciales donantes de los que se consiguen 30 utilizados, de los cuales se trasplantan 55 riñones. El resto fueron descartados por mala perfusión o signos de isquemia. Se encontró una asociación $(p=0.016)$ entre valores de capnometría durante la resucitación en los donantes utilizados $(\mu=22.8 \mathrm{mmHg}$ ) frente a los donantes no utlizados para el trasplante $(\mu=17.35 \mathrm{mmHg})$.

Conclusiones: Se ha demostrado que los valores de capnometría durante las maniobras de resucitación ofrecen un marcador a tener en cuenta en relación con la viabilidad de los órganos a trasplantar en la donación en asistolia no controlada.

(c) 2018 Elsevier España, S.L.U. y SEMICYUC. Todos los derechos reservados.

\section{Introduction}

Capnometry, or end-expiratory $\mathrm{CO}_{2}\left(\mathrm{EtCO}_{2}\right)$, is a very useful tool in the emergency care setting for assessing the hemodynamic condition of the patient, particularly in situations of cardiopulmonary arrest (CPA), where it has been shown to be a prognostic indicator and an appropriate means of support in resuscitation maneuvering. ${ }^{1,2}$ Likewise, in less seriously ill patients, capnometry affords information about ventilation status and tissue perfusion. ${ }^{3-5}$ The latest recommendations on the management of CPA are clear about the use of capnography ${ }^{6}$ as a method for checking endotracheal tube positioning and for the prognosis of CPA in combination with other indicators. Accordingly, in recent years capnometry has become established as an essential clinical tool in the critically ill. ${ }^{7-11}$

The assessment of all potential organ donors comprises a series of tests and markers for evaluating suitability as a donor and safety for the recipient. Capnography is increasingly used among such markers, since it allows indirect but precise assessment of tissue perfusion of the organs of the possible donor. ${ }^{12,13}$

In the concrete case of uncontrolled non-heart beating donation (NHBD), these indicators are especially relevant, since decision making must be made in a shorter period of time. Most NHDB procedures in Spain have an efficacy rate of about $70 \%{ }^{14}$; it is therefore of interest to establish scientifically tested indicators that are effective in selecting possible donors. Capnography could be one of these indi- cators, and although this field has not been extensively developed to date, a number of studies have suggested that capnography may be a method to be taken into account. ${ }^{12}$

In view of the above, the present study was designed to assess capnography as a predictor of the viability of renal grafts in NHBD, exploring the relationship between application of the technique during the donor management process in the emergency care setting and the condition of the possible renal grafts obtained.

\section{Patients and methods}

A retrospective study was made of the interventions carried out for kidney transplantation from non-heart beating donors in Doce de Octubre University Hospital (Madrid, Spain) between January 2013 and May 2017.

Type IIA NHBD according to the Maastricht classification (modified, Madrid 2011) ${ }^{15}$ refers to donation from patients that have suffered cardiac arrest and who following resuscitation maneuvering by the out-hospital emergency services, without the recovery of pulse, are transferred to hospital under cardiac massage with mechanical chest compression, intubation and mechanical ventilation.

Once resuscitation maneuvering was found to be ineffective and the transplantation coordinator of the hospital had been alerted, the donors were transferred with mechanical chest compression (LUCAS2 ${ }^{\circledR}$ ) and mechanical ventilation using an Oxylog 3000 plus $^{\circledR}$ transport respirator. In hospital, 
the possible donors were subjected to extracorporeal circulation and the kidneys were preserved under normothermal abdominal perfusion until harvesting.

The case selection criteria comprised all potential donors transferred to Doce de Octubre University Hospital in the context of NHBD. The inclusion criteria were therefore the same as those applied to NHBD: patients between 18-60 years of age, with a time to onset of resuscitation maneuvering of under $15 \mathrm{~min}$ from the time of CPA, arrival in hospital in less than 120 min from the time of CPA, with no bleeding abdominal injuries, and with no suspected neoplastic disease, infections or parenteral drug abuse. The potential donors were subjected to normothermal extracorporeal membrane oxygenation (ECMO) according to the routine procedure described in the literature. ${ }^{13}$ The recipients in turn were patients subjected to hemodialysis and on the transplant waiting list.

The study was approved by the Ethics Committee of Francisco de Vitoria University (Madrid, Spain).

The following data were collected corresponding to the donors registered by the transplantation coordinator of Doce de Octubre University Hospital: gender, age, smoking, background diseases, time of CPA, time of start of advanced life support (ALS) measures, time of patient hospital transfer, time of arterial catheterization, time of start of extracorporeal circulation, time of clamping prior to organ harvesting, transplantation or not of the kidney, and the capnography values at the start of cardiopulmonary resuscitation (CPR), half-way through the emergency services care period, and at the time of in-hospital transfer. On a consensus basis among the authors, with their experience in interpreting capnographic data, and in accordance with the literature, ${ }^{16}$ the capnography values were classified as normal or adequate if over $30 \mathrm{mmHg}$.

We also recorded the cold ischemia time, defined as the time between organ harvesting from the donor and its implantation in the recipient.

For the measurement of $\mathrm{EtCO}_{2}$, and once the patient was intubated, use was made of a LifePack $15^{\circledR}$ monitor / defibrillator (Physio-Control, Redmond, WA, USA), with measurements based on side stream technology.

The hospital case histories of the transplant patients were reviewed for compilation of the following variables: gender, age, cause of chronic renal failure, duration of dialysis before transplantation, HLA system incompatibilities, presence of primary renal failure, acute graft rejection, delayed renal function (over 7 days), measurement of serum creatinine (day 1 , day 7 , month 3 , month 6, 1 year, 1.5 years, 2 years, 3 years and 4 years) and proteinuria (day 1 , day 7 , month 3, month 6, 1 year, 1.5 years, 2 years, 3 years and 4 years), graft survival and patient survival at 12 months.

A descriptive statistical study was made, reporting quantitative variables as the mean \pm standard deviation (SD) and qualitative variables as frequencies. Normal distribution of the quantitative variables was assessed using the ShapiroWilk test. With regard to the comparative study, and for a limited sample size, we performed univariate analysis with assessment of the association between qualitative variables using the chi-squared test and Fisher exact test if any of the expected values was less than 5 . Associations between qualitative and quantitative variables in turn were evaluated with the nonparametric Mann-Whitney U-test.
Table 1 Capnometry $\left(\mathrm{EtCO}_{2}\right)$ data during organ donor management.

\begin{tabular}{llll}
\hline & $\begin{array}{l}\text { Mean }(\mathrm{mmHg}) \\
\pm \mathrm{SD}\end{array}$ & $\begin{array}{l}\text { Maximum } \\
(\mathrm{mmHg})\end{array}$ & $\begin{array}{l}\text { Minimum } \\
(\mathrm{mmHg})\end{array}$ \\
\hline $\begin{array}{l}\text { Initial } \\
\text { capnometry }\end{array}$ & $22.8 \pm 12$ & 57 & 5 \\
$\begin{array}{c}\text { Transfer } \\
\text { capnometry }\end{array}$ & $26.8 \pm 18.3$ & 100 & 4 \\
\hline
\end{tabular}

Table 2 Comparison between used and non-used organ donors.

\begin{tabular}{llll}
\hline & $\begin{array}{l}\text { Used } \\
(\mathrm{n}=30)\end{array}$ & $\begin{array}{l}\text { Non-used } \\
(\mathrm{n}=7)\end{array}$ & $\mathrm{p}$-Value \\
\hline Age (years) & 4.83 & 40.43 & 0.051 \\
$\begin{array}{l}\text { Male gender } \\
\text { Initial }\end{array}$ & 26 & 7 & 0.306 \\
$\quad \begin{array}{l}\text { capnometry } \\
\quad(\mathrm{mmHg})\end{array}$ & 26.6 & 21.57 & 0.471 \\
$\begin{array}{l}\text { Final } \\
\text { capnometry }\end{array}$ & 22.8 & 17.35 & 0.016 \\
$\quad(\mathrm{mmHg})$ & & & \\
$\begin{array}{l}\text { Disease (\%) } \\
\text { Smoker (\%) }\end{array}$ & 3.33 & 0 & \\
$\begin{array}{l}\text { Time CPA-ALS } \\
\quad(m i n)\end{array}$ & 12.6 & 92.85 & 0.624 \\
$\quad$ & & 9.43 & 0.119 \\
\hline
\end{tabular}

Statistical significance was considered for $p<0.05$. The SPSS version 21.0 statistical package (SPSS ${ }^{\circledR}$ Inc., Chicago, IL, USA) for MS Windows was used throughout.

\section{Results}

A total of 37 donors were recorded during the period of the study, with a mean age of $44.81 \pm 6.64$ years. Of these, 34 were males $(91.9 \%)$ and three females $(8.1 \%)$. The mean time from CPA to the start of ALS was $12 \pm 4.83 \mathrm{~min}$. The mean time elapsed from the confirmation of donor death to organ harvesting was $3.61 \pm 0.54 \mathrm{~h}$. The $\mathrm{EtCO}_{2}$ values at the start of ALS, half-way through the emergency services care period, and at the time of in-hospital transfer are shown in Table 1.

Thirty donors yielded organs ( $\mathrm{n}=55$ kidneys). Table 2 compares the donors that were used versus those not used, for each of the donor group variables: no significant differences were observed, apart from the capnometry values.

A total of $83.6 \%$ recipients $(n=46)$ were males and 9 females, with a mean age of $49.59 \pm 9.10$ years. The mean duration of dialysis among the recipients was $1.45 \pm 1.11$ years.

A total of $81.2 \%$ of the grafts ( $n=45$ patients) presented delayed renal function, with a mean of $17.76 \pm 9.01$ days. These patients required an average of $4.56 \pm 2.27$ hemodialysis sessions until the graft started to function normally. No primary renal failures were recorded.

Likewise, no statistically significant association was observed between the initial and final capnography values, 
Table 3 Comparison of delayed renal function with the capnometry data.

\begin{tabular}{llll}
\hline & No $(\mathrm{n}=10)$ & Yes $(\mathrm{n}=45)$ & $\mathrm{p}$-Value \\
\hline $\begin{array}{c}\text { Initial } \\
\text { capnometry } \\
\text { (mmHg) }\end{array}$ & 24.67 & 27.43 & 0.963 \\
$\begin{array}{c}\text { Transfer } \\
\text { capnometry } \\
\text { (mmHg) }\end{array}$ & 26.33 & 19 & 0.235 \\
$\begin{array}{c}\text { Age (years) } \\
\text { Cold ischemia } \\
\text { time (h) }\end{array}$ & 8.875 & 15.023 & 0.144 \\
$\begin{array}{c}\text { Warm ischemia } \\
\text { time (h) }\end{array}$ & 3.478 & 3.555 & 0.729 \\
$\begin{array}{c}\text { Time PCS-ALS } \\
\text { (min) }\end{array}$ & 9.22 & 11.02 & 0.245 \\
\hline
\end{tabular}

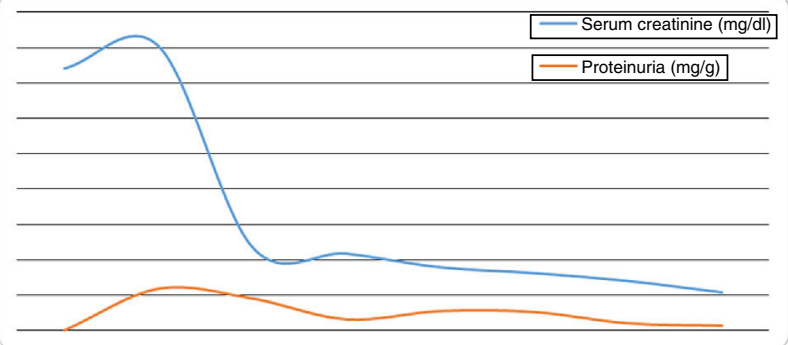

Figure 1 Time course of the serum creatinine concentrations and proteinuria in the graft recipients.

age, cold and warm ischemia time, or time from CPA to basic life support, and the delay in renal function (Table 3 ).

The determinations referred to serum creatinine and proteinuria over follow-up of the recipients are reported in Fig. 1. The graft survival rate was $100 \%$ in all the studied patients, with no transplant-related deaths.

\section{Discussion}

Non-heart beating donation has become an important source of organs for transplantation, particularly kidneys, in the course of the last decade. ${ }^{14,16}$ According to data from the Spanish National Transplantation Organization (Organización Nacional de Trasplantes), a total of 126 kidneys, 15 lungs and 9 livers were transplanted in the year 2016. ${ }^{15}$ However, the conditions characterizing CPA imply increased tissue vulnerability and aggression. Although it seems logical for renal grafts obtained from NHBD to suffer greater stress than organs obtained from other types of donors, the study carried out by Gagandeep et al. ${ }^{17}$ recorded no major differences between kidneys obtained from NHBD and those obtained from brain dead donors.

Capnometry is commonly used in the monitorization of critical patients, and particularly in the context of CPA, where it has been shown to act as a prognostic indicator and marker of the adequacy of ALS maneuvering. ${ }^{18,19}$ Different studies have warranted the relationship between capnography values and adequate organ perfusion. ${ }^{2}$ In this regard, a number of studies have explored variables or factors capa- ble of predicting the viability of organs for donation, taking into consideration donors of this kind, in the same way as has been done in predicting sepsis in the out-hospital setting ${ }^{20-22}$ or admission to the Intensive Care Unit (ICU). ${ }^{23}$

Our review of the literature yielded no studies on capnography as a predictor of graft evolution, with the exception of a letter to the Editor describing liver graft rejection due to ischemia in an uncontrolled non-heart beating donor, in which the capnography readings were seen to be low during resuscitation maneuvering. ${ }^{14}$

Capnography values have been related to the validity of harvested kidneys. In this respect, kidneys rejected due to ischemia or poor perfusion were found to come from donors with lower $\mathrm{EtCO}_{2}$ readings than those in which organ transplantation was effectively carried out - with statistically significant findings at the time of transfer. This observation is consistent with the data found in the literature on the association between capnography and tissue perfusion, ${ }^{24}$ though it must be underscored that other factors may also condition graft viability, such as the duration of cardiopulmonary resuscitation, among others. However, these factors have only been referred to in a clinical case published in 2011 by Cordero-Escobar et al. ${ }^{25}$

Lower capnometry values have been recorded at the time of transfer in the case of kidneys that were not successful and had to be rejected to the effects of donation $(p=0.016)$. No such data have been recorded to date in the context of NHBD resulting in renal transplantation, though information is indeed available in relation to lung grafting, where higher capnometry readings have been shown to be correlated to increased organ viability in transplant patients. ${ }^{26,27}$

Lower capnometry values have been documented at the time of transfer in kidneys with delayed renal function, though the results were not statistically significant - possibly because of limitations in sample size. However, the data contrasting patients with delayed renal function $(19 \mathrm{mmHg})$ versus those without delayed function $(26.33 \mathrm{mmHg})$ suggest that a study with a larger sample size and involving a prospective and controlled design could produce more convincing conclusions in this key aspect referred to organ donors and increased patient quality of life. With regard to the delay in renal function, the patients of the series presented an average overall delay of 17.76 days, which is consistent with the available literature, which describes a delay in renal function in NHBD recipients of 15 days versus 7 days in patients receiving grafts from brain dead donors. ${ }^{28}$

Another aspect that has been cited as possibly conditioning delays in renal function is the duration of cold ischemia. In this respect, although no statistically significant differences were observed between patients without delayed renal function $(8.875 \mathrm{~h})$ versus those with delayed function (15.023) $(p=0.144)$, the evidence suggests that there is a clear association between cold ischemia time and delayed renal graft function, as observed in the study published by Emiroğlu et al. in 2005. ${ }^{28}$

With regard to the possible complications after transplantation, an association has only been found between the $\mathrm{EtCO}_{2}$ values and the delay in renal graft function after transplantation - though statistical significance was not reached $(p=0.062)$. This finding may be conditioned by the limited sample size involved (one of the limitations of this retrospective study). Accordingly, it has been necessary to 
exclude those possible donors with last capnography readings that were not close in time to in-hospital transfer. The capnometry data are recorded according to the criterion of the healthcare staff, and in some cases the last capnography readings were obtained far in time from the time of transfer. As a result, with a view to securing a more reliable analysis, some of these cases were obviated.

The limitations of the present study are clear and evident, and need to be resolved by the research team in future studies, since on the basis of the data generated by our analysis, we can only insist on the need for a prospective study involving a large sample size in order to confirm all the assumptions of this first evaluation of the capnometry results in NHBD patients, with a view to better understanding the crucial role of capnography and posterior intervention on the part of the emergency services.

In conclusion, capnometry could be a factor to be considered in the selection of possible non-heart beating donors, as it is related to the rejection of organs for transplantation purposes. On the other hand, further research is required, involving larger sample sizes and more adequate designs for the appropriate collection of variables, with a view to confirming the hypothesis that the capnography values recorded during resuscitation are related to delayed renal graft function after transplantation.

\section{Authorship}

Alonso Mateos and Alicia Villar carried out the clinical interpretation of the statistical analysis.

David Varillas performed the statistical analysis and editing and drafting of the manuscript, together with Alonso Mateos and Alicia Villar.

Carlos Rubio and Alicia Villar compiled the patient data from the case history records of Doce de Octubre University Hospital.

Francisco José del Río and Amado Andrés facilitated access to the data and endorsed the study.

Alonso Mateos, David Varillas and Alicia Villar are members of the Donation and Transplant Research Group of Francisco de Vitoria University.

\section{Conflicts of interest}

The authors declare that they have no conflicts of interest.

\section{References}

1. Pantazopoulos C, Xanthos T, Pantazopoulos I, Papalois A, Kouskouni E, lacovidou N. A review of carbon dioxide monitoring during adult cardiopulmonary resuscitation. Heart Lung Circ. 2015;24(11):1053-61.

2. Paiva EF, Paxton JH, O'Neil BJ. The use of end-tidal carbón dioxide $\left(\mathrm{ETCO}_{2}\right)$ measurement to guide management of cardiac arrest: A systematic review. Resuscitation. 2018;123:1-7.

3. Hällsjö Sander C, Hallbäck M, Wallin M, Emtell P, Oldner A, Björne H. Novel continuous capnodynamic method for cardiac output assessment during mechanical ventilation. $\mathrm{Br} \mathrm{J}$ Anaesth. 2014;112(5):824-31.

4. Mosing M, Kutter AP, Iff S, Raszplewicz J, Mauch J, Bohm $\mathrm{SH}$, et al. The effects of cardiac output and pulmonary arterial hypertension on volumetric capnography derived- variables during normoxia and hypoxia. J Clin Monit Comput. 2015;29(1):187-96.

5. Kotake Y, Yamada T, Nagata H, Suzuki T, Serita R, Katori $\mathrm{N}$, et al. Improved accuracy of cardiac output estimation by the partial $\mathrm{CO} 2$ rebreathing method. J Clin Monit Comput. 2009;23(3):149-55.

6. Soar J, Nolan JP, Böttiger BW, Perkins GD, Lott C, Carli P, et al. Adult advanced life support section Collaborators. European resuscitation council guidelines for resuscitation 2015: Section 3. Adult advanced life support. Resuscitation. 2015;95: $100-47$.

7. Nassar BS, Schmidt GA. Capnography during critical illness. Chest. 2016;149(2):576-85.

8. Sinha P, Soni N. Comparison of volumetric capnography and mixed expired gas methods to calculate physiological dead space in mechanically ventilated ICU patients. Intensive Care Med. 2012;38(10):1712-7.

9. Suarez-Sipmann F, Bohm SH, Tusman G. Volumetric capnography: the time has come. Curr Opin Crit Care. 2014;20(3):333-9.

10. Nolan JP, Kelly FE. Airway challenges in critical care. Anaesthesia. 2011;66 Suppl 2:81-92.

11. Bhende MS, LaCovey DC. End-tidal carbon dioxide monitoring in the prehospital setting. Prehospital Emergency Care. 2001;5(2):208-13.

12. Simón NV. Estudio de las maniobras de reanimación como medida de preservación inicial en el donante no controlado a corazón parado. Tesis Doctoral. Universidad Complutense de Madrid. Facultad de Medicina; 2017.

13. Donación en asistolia en España: Situación actual y recomendaciones. Documento de Consenso Nacional. 2012.

14. Informe de donación en asistolia 2016. Organización Nacional de Trasplantes. 2017.

15. Miñambres E, Rubio JJ, Coll E, Domínguez-Gil B. Donation after circulatory death and its expansion in Spain. Curr Opin Organ Transplant. 2018;23:120-916.

16. Bagwell TA, Abramo TJ, Albert GW, Orsborn JW, Storm EA, Hobart-Porter NW, et al. Cerebral oximetry with blood volume index and capnography in intubated and hyperventilated patients. Am J Emerg Med. 2016;34(6):1102-7.

17. Gagandeep S, Matsuoka L, Mateo R, Cho YW, Genyk Y, Sher L, et al. Expanding the donor kidney pool: utility of renal allografts procured in a setting of uncontrolled cardiac death. Am J Transplant. 2006;6:1682-8.

18. Cha KC, Kim HJ, Shin HJ, Kim H, Lee KH, Hwang SO. Hemodynamic effect of external chest compressions at the lower end of the sternum in cardiac arrest patients. J Emerg Med. 2013;44:691-7.

19. Pernat A, Weil MH, Sun S, Tang W. Stroke volumes and end-tidal carbon dioxide generated by precordial compression during ventricular fibrillation. Crit Care Med. 2003;31(6): 1819-23.

20. Hunter CL, Silvestri S, Dean M, Falk JL, Papa L. End-tidal carbon dioxide is associated with mortality and lactate in patients with suspected sepsis. Am J Emerg Med. 2013;31(1):64-71.

21. Hunter C, Stone A, Ralls G. EtCO2 to Identify Severe Sepsis: Prehospital sepsis screening and ED alerts in Orange County, Fla. JEMS. 2016;41(9):40-7.

22. Guirgis FW, Williams DJ, Kalynych CJ, Hardy ME, Jones AE, Dodani S, et al. End-tidal carbon dioxide as a goal of early sepsis therapy. Am J Emerg Med. 2014;32(11):1351-6.

23. McGillicuddy DC, Tang A, Cataldo L, Gusev J, Shapiro NI. Evaluation of end-tidal carbon dioxide role in predicting elevated SOFA scores and lactic acidosis. Intern Emerg Med. 2009;4(1):41-4.

24. Cambra Lasaosa FJ, Pons Odena M. Pulse oximetry and capnography. An Pediatr (Barc). 2003;59(3):259-64.

25. Cordero Escobar I, Rey Martínez B, Company Teuler R, Pérez Carbonell A. Sugammadex in a man with a transplanted kidney: a case report. Rev Esp Anestesiol Reanim. 2011;58(10):611-3. 
26. Srinivasa V, Kodali BS, Hartigan PM. Evolving capnograms after single lung transplant. Anesth Analg. 2004;98(5):1504.

27. Rai HS, Boehm JK, Stoller JK. Biphasic capnogram in a single-lung transplant recipient: a case report. Respir Care. 2014;59(8):E108-9.
28. Summers DM, Johnson RJ, Hudson A, Collett D, Watson CJ, Bradley JA. Effect of donor age and cold storage time on outcome in recipients of kidneys donated after circulatory death in the UK: a cohort study. Lancet. 2013;381(9868):727-34. 